\title{
Pop Up Book Learning Media In Inclusive Schools
}

${ }^{1}$ I Ketut Gading, I Wayan Widiana ${ }^{2}$, I Gusti Ngurah Perdana Merata Putra ${ }^{3}$, Ni Nyoman Rediani ${ }^{4}$, Ikrima Maulida ${ }^{5}$

${ }^{1}$ Department of Guidance and Counceling, ${ }^{2,3,4,5}$ Department of Elementary Teacher Education Faculty of Education, Ganesha University of Education, Singaraja, Indonesia e-mail: \{iketutgading@undiksha.ac.id ${ }^{1}$,wayanwidiana85@undiksha.ac.id², ngurahperdana49@gmail.com ${ }^{3}$, nyoman.rediani@undiksha.ac.id ${ }^{4}$, ikrima@undiksha.ac.id $\left.{ }^{5}\right\}$

\begin{abstract}
Inclusive education in Bengkala village cannot currently be running well and conducive. Students still show low social attitudes because students are still learning and playing with other normal themes and experiencing students with special needs lack of confidence. Therefore, teachers play an important role in the learning process and developing children's social skills. This study aimed to analyze the effect of pop up book media on the fourth-grade students' social science competency knowledge in inclusive schools. This research was a type of pre-experimental research (pre-experimental research). The design used in this study was one group pre-test post-test design. This study's population were 14 students in the fourthgrade who were simultaneously used as samples. The data collection method used in this research was the learning outcome test method. The data collection instrument used in this study was an objective test consisting of 30 items. The data analysis used in this study was the t-test for correlated samples. All tests were carried out using SPSS 21.0 for Windows. The results showed that $t_{\text {count }}$ was 18.56 thus it can be concluded that the pop-up book learning media positively affects the fourth-grade students' social science competency knowledge in inclusive schools.
\end{abstract}

Keywords: pop up book, inclusive school

Article Received: 10 August 2020, Revised: 25 October 2020, Accepted: 18 November 2020

\section{Introduction}

Inclusive schools are educational units that provide education for all students at the same school without discrimination, are friendly, and humanist to optimize the development of the potential of all students to become empowered and dignified human beings (D'alessio et al., 2010; Sabando et al., 2019; Spörer et al., 2020; Triyanto \& Permatasari, 2016). Inclusion schools provide equal opportunities for all children to participate physically, socially, and academically with their peers (Diahwati et al., 2016; Sabando et al., 2019). Education carried out in inclusive schools aims to (a) provide the widest possible opportunity for all students who have physical, emotional, mental, and social disabilities or have the potential for intelligence and special talents to obtain quality education according to their needs and abilities, (b) realizing education that respects diversity and is not discriminatory for all students (Triyanto \& Permatasari, 2016). To realize these educational goals, of course, a collaboration of three components is needed, policy, culture, and the learning process (Oswald, 2014).

The implementation of inclusive education must pay attention to how students will be taught. Inclusive students cannot face the same obstacles as other normal children (Claudia et al., 2015). The research studies conducted focus more on teachers' attitudes in implementing learning. Teachers think that they are not 
competent in teaching inclusive children. Teachers always hesitate and think negatively about inclusive education (De Boer et al., 2011).

Another problem is that in inclusive education in regular classes, students experience weaknesses in social relationships (Bossaert et al., 2013; Schwab et al., 2018). Students with special needs have lower learning outcomes than their peers without special needs (Zurbriggen et al., 2018). Previous research is more about how the learning outcomes of children with special needs in regular classes (Armstrong et al., 2011) study outcomes and social attitudes of all students that must be considered (Schwab et al., 2020). So, it can be said that inclusive education students have reduced social abilities and indirectly affect student learning outcomes.

Based on the observation results, students seemed to lack concentration in participating in learning, so that students did not understand the delivery of material provided by the teacher. Students also seem to pay no attention to the teacher. Communication between teachers and students is a little hampered because two students are mute. The learning media used are inappropriate because the teacher only uses image media to be boring during the learning process. Based on the results of interviews conducted with fourth-grade teachers of SD Negeri 2 Bengkala, it was found that the teacher had difficulty giving lessons to some students because two students had speech disorders or mute disabilities. This situation shows the importance of communication and the use of learning media to increase students' knowledge. Based on this description, it can be said that student-teacher, studentstudent social relations are very important because, with social relationships, students will find it easier to follow learning.

The teacher's role is very important in forming social relationships or fostering interaction between students with special needs and normal students and studentteacher relationships (Liu et al., 2015; O'Connor et al., 2011; Sointu et al., 2017). One of the subjects that can provide opportunities for students to develop their social skills in Social Studies. Social studies are a compulsory subject in schools designed based on phenomena, problems, and social reality with an interdisciplinary approach involving branches of social sciences and humanities such as citizenship, history, geography, economics, sociology, and anthropology (Diacopoulos \& Crompton, 2020). Social studies learning aims so that students can recognize concepts related to community life, have the basic ability to think logically and critically, have commitment and awareness of social and human scores, and have the ability to communicate, collaborate and be competent in society. That is diverse at the local, national, and global levels (Hutami \& Hastuti, 2019; Maulida et al., 2020; Rudi et al., 2016; Rusmawan, 2013). Therefore, the social studies subject in elementary schools aims to enable students to develop their knowledge, scores , attitudes, and social skills. To realize these learning objectives, the interaction between learning components is needed. One of the important components of the learning process is learning media.

However, as previously explained, one of the problems faced in inclusive schools' learning is the media used. Likewise, in social studies learning media that is owned is still very lacking. Currently, available learning media are only for normal students. If this is allowed, it will impact the learning process. For inclusive education, media presence helps increase students' knowledge and understanding (Sari et al., 2019). Learning media are anything that can be used to transmit messages in the form of information, stimulate the thoughts, feelings, attention, and abilities of students so that they can encourage their interest in learning (Hartini et al., 2017; Herayanti et al., 2017; 
Rahmi et al., 2019). Learning media helps children's psychological development in terms of learning because psychologically teaching aids in learning media make it very easy for students to learn because media can make abstract things more concrete (real). One of the media that can be developed and created to help children in inclusive schools is the pop-up book media.

Pop up book learning media is a book that has moving parts or has threedimensional elements and provides a more interesting visualization of the story, starting from the display of images that can move when the page is opened (Karisma et al., 2020; Masturah et al., 2018; Mustika \& Ain, 2020; Mustofa \& Syafi'ah, 2018). This pop-up book's unique visualization can stimulate students during the presentation of the material, develop their thinking capacity, and easily remember the book's material. Pop up book media can help teachers deliver learning material and can help students understand learning material. Pop up book media also provides a special experience for readers because it involves readers in the story, such as sliding, opening, and folding parts of the pop-up book (Sentarik $\&$ Kusmariyatni, 2020). Some of the advantages of pop up book media compared to other media are (1) it can display images to be more attractive, (2) it can be used as teaching materials which can be used individually or in groups, (3) its use is very practical and can increase enthusiasm for learning students, (4) have a unique appearance, and this is an advantage of pop up book media compared to other media, (5) has an image dimension that arises when the page is opened (Masturah et al., 2018; Mustofa \& Syafi'ah, 2018).

Analysis of research findings conducted by Diyantari et al., (2020) the snowball throwing learning model assisted by pop up book media has a significant effect on science competency in fourth- grade elementary school science knowledge because learning using snowball throwing assisted by pop up book media has a positive towards the competence of elementary students' science knowledge through stages in the learning process that trains students to make it easier for students to understand. The research results conducted by Nikmah et al., (2019) pop up book media affected student learning outcomes in fourth grade SDN Sukorejo 02 Semarang. The average post-test score is higher than the pre-test score after being treated using a shared learning model. Besides that, the results of the t-test calculation strengthen it. It is obtained tcount for learning outcomes of 2.135 and $t_{\text {table }}$ of 1.711 because $t_{\text {count }}$ $(2.135)>t_{\text {table }}(1.711)$ then this shows that the t-test of learning outcomes is significant. The results of research conducted by Arifin et al., (2017) state that the ability to reason can be increased from a structural level to a multi structural level with a very significant increase based on the t-test score, student learning outcomes also increase with the degree of difference in pretest-posttest scores in the category is based on N-Gain analysis. Students' positive response about guided inquirybased learning assisted by pop-up textbooks makes it very easy for students to reason, and learning becomes easy and interesting. With the pop-up book media, it will have a positive impact on learning outcomes. Students are more interested in participating in learning.

This study aims to analyze the effect of pop up book media on the fourth-grade students' social science competency knowledge in inclusive schools. The novelty of this research is applying pop up book learning media in inclusive schools. The pop-up book learning media applied in this research increases students' knowledge, especially in social science learning. Research on pop-up book learning media mostly researched science material and improved science learning outcomes and is only applied in regular, 
not inclusive schools. However, in this study, pop up book learning media was implemented to improve social studies knowledge in inclusive schools. Pop up book media is suitable for use in the learning process of speech hearing deaf children because the learning style of deaf children is visual and a little bit kinesthetic. It causes visual learning in deaf children to lead to the eyes or vision. In the teaching and learning process, the teacher uses visual media and uses body language, and facial expressions.

\section{METHODS}

\section{Types of Research}

This research is a type of preexperimental research (pre-experimental research). The design used in this study was a one group pre-test post-test design. The treatment given in this study was the use of pop up book learning media. Before the treatment was carried out, a pre-test was given to determine the student's social science competency knowledge. After treatment, the class was given a post-test to determine the change in the student's social science competency knowledge. The material presented in the pop-up book learning media is material about economic activities and types of work. The research stages are first, developing pop up book media. Media developed using ADDIE, analysis, design, development, implementation, evaluation. The stages of the analysis carried out include needs analysis, student characteristic analysis, and material analysis. After the analysis stage, the planning stage (design), a popup book media design is carried out with material on economic activities and the types of work in fourth-grade elementary school to draft the material to be outlined. In the media, after the draft material is developed, it is continued with the development stage. At the development stage, the pop-up book media was made according to the material being consulted. An expert will test the pop-up book media completed to review the media being developed. Expert testing is carried out by providing a pop-up book media assessment sheet to the experts consisting of two lecturers and one fourth grade teacher. Second, the second stage of this research is to apply pop up book media to all samples. Students in fourth-grade elementary school are assisted in the learning process with pop up book media, following the material being studied. Before being taught using Pop Up Book media, the students first did a pre-test. And third, after the material has been given, the final stage of this research is giving a post-test to determine changes in student learning outcomes after the application of pop up book media.

\section{Population and Sample}

This research will be conducted in Bengkala Village, Buleleng Regency, Bali Province. Bengkala Village is one of the small villages with approximately 3031 most farmers (Aryawibawa et al., 2018). Bengkala village is known as kolok village because there is a large writing community with julah mute. Children learn sign language from both parents directly. This is different from places outside the village (Moriarty, 2020). In Bengkala Village, there is the only inclusive school in Bali, where normal students study together with "KOLOK" students. One of the primary schools chosen was SD Negeri 2 Bengkala. This study's population was all fourth-grade students at SD Negeri 2 Bengkala, totaling 14 students. The existing population is selected using a saturated sample technique using all population members as a sample.

\section{Method of Collecting Data}

The data collected in this study were the students' knowledge competency scores in the fourth-grade students of social studies subjects. The data collection method used in this research is the test method. The data collection instrument used in this study was an objective test consisting of 30 items. The indicators for 
making objective tests can be seen in Table 1. Before using the instrument, it was tested for validity, reliability testing, difficulty level, and item difference. The test of this question was conducted outside the research area. The questions were analyzed using the product-moment correlation formula and the KR-20 reliability after completing the test questions. Of the 35 questions made after being analyzed, 30 questions were obtained that were feasible to use.

Table 1. Objective test indicators

\begin{tabular}{|c|c|c|c|c|c|}
\hline \multirow[t]{2}{*}{ Indicator } & \multicolumn{4}{|c|}{ Cognitive Level } & \multirow{2}{*}{$\begin{array}{l}\text { Number of } \\
\text { Questions }\end{array}$} \\
\hline & C1 & $\mathrm{C2}$ & C3 & $\mathrm{C} 4$ & \\
\hline $\begin{array}{l}\text { 3.3.1. State the } \\
\text { economic activities } \\
\text { and livelihoods of } \\
\text { residents in an area }\end{array}$ & $\begin{array}{l}1,2,3,4,5,6, \\
7,8,9 \\
10,11,12\end{array}$ & & & & 12 \\
\hline $\begin{array}{l}3.3 .2 \text { Describe the } \\
\text { types of economic } \\
\text { activity }\end{array}$ & $\begin{array}{l}13,14,15,1 \\
6\end{array}$ & & & & 4 \\
\hline $\begin{array}{l}\text { 3.3.3 Describe the } \\
\text { types of work }\end{array}$ & 17,18 & & & & 2 \\
\hline $\begin{array}{l}\text { 3.3.4 Cite examples } \\
\text { of types of work in } \\
\text { the neighborhood }\end{array}$ & $\begin{array}{l}19,20,21,2 \\
2,23\end{array}$ & & & & 5 \\
\hline $\begin{array}{l}3.3 .5 \text { Determine the } \\
\text { type of person's work } \\
\text { in social life in the } \\
\text { surrounding } \\
\text { environment }\end{array}$ & & & $\begin{array}{l}24,25, \\
26\end{array}$ & & 3 \\
\hline $\begin{array}{l}\text { 3.3.6. Distinguish the } \\
\text { types of economic } \\
\text { activities carried out } \\
\text { in the surrounding } \\
\text { environment }\end{array}$ & & & & 27,28 & 2 \\
\hline $\begin{array}{l}\text { 3.3.7 Distinguishing } \\
\text { the type of person's } \\
\text { work in social life }\end{array}$ & & & & 29,30 & 2 \\
\hline Total & & & & & 30 \\
\hline
\end{tabular}

\section{Data Analysis}

The data that has been collected, both pre-test and post-test, will use the t-test. The t-test was conducted to determine the effectiveness level of the pop-up book learning media. Data Before the pop-up book learning media is applied, it is given a pre-test. Furthermore, after the pop-up book media was implemented, all fourthgrade students were given a post-test. The 
t-test is carried out for correlated samples based on the pre-test and post-test scores, provided that the t-table is at the $5 \%$ significance level, tcount. Thus, the $t_{\text {count }}$ score is greater than the t-table score, so that $\mathrm{H}_{0}$ is rejected and $\mathrm{H}_{1}$ is accepted. All tests were carried out using SPSS 21.0 for windows.

\section{Result and Discussion}

\section{Result}

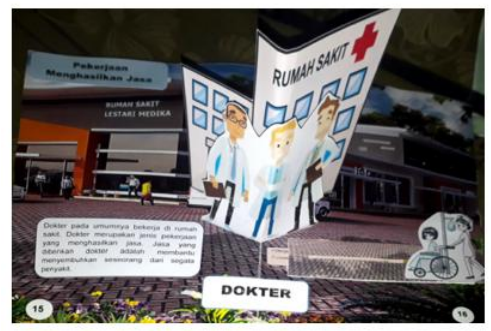

Figure 1. Pop up book media content

The validity test was carried out at the development stage following the development model used, the ADDIE model. The stages of developing the ADDIE model are analysis, design, development, implementation, evaluation. The stages of the analysis carried out include needs analysis, student characteristic analysis, and material analysis. After the analysis stage, the planning stage (design), a pop-up book media design is carried out with material on economic activities and the types of work in fourth-grade elementary school to draft the material to be outlined. In the media, after the draft material is developed, it is continued with the development stage. At the development stage, the pop-up book media was made according to the material being consulted. An expert will test the pop-up book media that has been completed to review the

\section{Pop Up Book media development}

This development research product is a pop-up book media containing material on economic activities and work types. Economic activity materials and work types are developed from basic competencies (KD) in fourth grade. The pop-up book media produced in this study can be seen in Figure 1 and Figure 2.

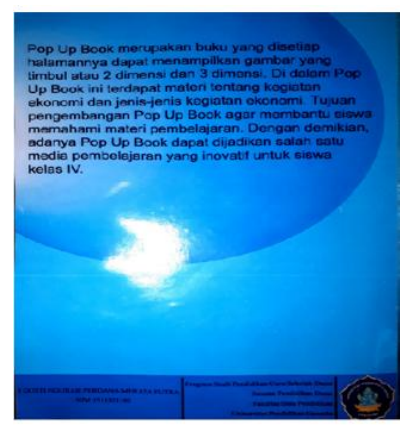

Figure 2. The back cover of the pop up book media

media being developed. Expert testing is carried out by providing a pop-up book media assessment sheet to the experts consisting of two lecturers and one fourth grade teacher.

The validity of the results of the development of pop up book learning media in (1) subject content experts are in very good qualifications with a percentage of the achievement level of $97.3 \%$ and there is no need for revisions to the material section, (2) according to learning media experts, the media developed is qualification is very good with a percentage of an achievement level of $90 \%$ and based on input, suggestions, and comments, a few revisions are made to improve the media, (3) learning design experts, the media developed is in very good qualifications with a percentage of achievement level of $91.7 \%$ and input, suggestions, and comments are made a 
little revision in order to improve the media, (4) individual trials are in very good qualifications with a percentage of achievement level of $95.8 \%$ and do not need to be revised, (5) small group trials are in very good qualifications with a percentage level of achievement of $93.6 \%$ and no need for revision, and (6) field trials are located the qualification is very good with a percentage level of achievement of $96.5 \%$ and does not need to be revised. Based on these validation results, the pop up book learning media developed were suitable to support the learning process in social studies subjects for the fourth grade of the 2018/2019 academic year at SD Negeri 2 Bengkala.

\section{Effectiveness of Pop Up Book Learning}

The pop-up book learning media's effectiveness level can be determined by providing a multiple-choice test instrument to all fourth-grade students of SD Negeri 2 Bengkala, as many as 14 students. Before the pop-up book learning media is applied, it is given a pre-test first. Furthermore, after the pop-up book media was implemented, all fourth-grade students were given a post-test. The results of the post-test are then used to find the results. The average pre-test score was 49.71, and the post-test average score was 91.21. Based on the pre-test and post-test scores, the $\mathrm{t}$-test is performed for correlated samples. The calculation results show that $\mathrm{db}=26$, the $\mathrm{t}$ table score is obtained at the $5 \%$ significance level of 2.056. Based on the calculations that have been done, the tcount is 18.56 . Thus, the $t$ count, which is 18.56 , is greater than the table score, so that $\mathrm{H} 0$ is rejected and $\mathrm{H} 1$ is accepted. There is a pop-up book learning media's effectiveness in increasing social science knowledge for fourth-grade students at SD Negeri 2 Bengkala, Kubutambahant, Buleleng.

\section{Discussion}

\section{Development of Pop Up Book Learning}

The Pop Up Book learning media developed is suitable for supporting the learning process in social studies subjects for the fourth grade of the 2018/2019 academic year at SD Negeri 2 Bengkala. It cannot be separated from how the learning design is developed. This pop-up book design was developed by paying attention to more attractive visuals media developed by paying attention to how a child interacts with his learning bucket. Interesting media will greatly assist students in the learning process. Interesting media certainly cannot be separated from the combination of colors, types of writing, and images that match the concepts being taught. In Pop Up Book media, color can improve children's feelings/psychology in participating in learning (Sentarik \& Kusmariyatni, 2020). Apart from color, the pop-up book media being developed has 3dimensional elements. Visually, 3D media has several functions, the attention function to attract students 'attention. The affective function, which is seen from the students' enjoyment of learning or reading, and the counterproductive function, provide context to help students understand reading content (Septian \& Tampubolon, 2015). The development of pop-up book media in learning is very influential on students' enthusiasm for learning because the design is attractive and visualizes abstract material (Karisma et al., 2020; Putra \& Parmiti, 2020). So, the development of media following the child's characteristics will greatly help the learning process. The eyes will be more attracted to beautiful colors and images, affecting students' feelings in participating in learning.

The results of this study are supported by research conducted by Diyantari et al., (2020) that the snowball throwing learning model assisted by pop up book media has a significant effect on science competency in fourth-grade elementary school science knowledge because learning using snowball throwing assisted by pop up book media has lead. 
Positive feedback on the competence of elementary students 'science knowledge through stages in the learning process trains students to facilitate students' understanding. The research results conducted by Nikmah et al., (2019) pop up book media affected student learning outcomes in fourth grade SDN Sukorejo 02 Semarang. The average post-test score is higher than the pre-test score, that is, after being treated using a shared learning model, besides that it is strengthened by the results of the t-test calculation, it is obtained tcount for learning outcomes of 2.135 and ttable of 1.711 because tcount (2.135)> t table (1.711) then This shows that the t-test of learning outcomes is significant. This study's results support the research conducted by Masturah (2018), which found that the Pop Up Book learning media developed effectively improved student learning outcomes in social studies learning, which showed that the average post-test score was 88.21 greater than the average pre-test score. 53.33 .

\section{Effectiveness of Pop Up Book Learning}

The results showed that tcount was 18.56. Thus, the $t$ count score, which is 18.56 , is greater than the t table score, so that $\mathrm{H} 0$ is rejected and $\mathrm{H} 1$ is accepted. There is a pop-up book learning media's effectiveness in increasing social science knowledge for fourth-grade students at SD Negeri 2 Bengkala, Kubutambahan, Buleleng. So, the learning process with Pop Up Book learning media positively influences and improves student social studies learning outcomes. It is inseparable from the application of the pop-up book media that has been developed.

Learning media are anything that can be used to transmit messages in the form of information, stimulate the thoughts, feelings, attention, and abilities of students so that they can encourage their interest in learning (Hartini et al., 2017; Herayanti et al., 2017; Rahmi et al., 2019). Learning media helps children's psychological development in terms of learning because psychologically teaching aids in learning media make it very easy for students to learn because media can make abstract things more concrete (real). So, learning media increases students' interest in learning. It will be easier to follow the learning and receive the material being learned (Hidayat et al., 2020; Pratama, 2017; Suarni et al., 2013). Students' high motivation and interest in the learning process will affect student learning outcomes. We know that visual media will greatly help students in Inclusion Schools, especially SD N 2 Bengkala, which consists of more deaf and normal children. With the appropriate media needed, students will be more motivated. High student motivation in the learning process will make learning more meaningful (Kusuma Wardani et al., 2017). Meaningful learning will be generated if students gain experience and develop emotional intelligence, and the learning process is carried out with a constructive approach (Angela, 2014; Kostiainen et al., 2018). meaningful learning will have an impact on student learning outcomes. Students obtain student learning outcomes after carrying out knowledge, attitudes, and skills (Marfuah, 2017). Students learn actively to develop and build their knowledge (Argikas \& Khuzaini, 2016; Ismail, 2018; Rencus, 2017).

Pop-up book media provide opportunities for students to interact with learning resources and peers. The existence of an interaction between all students without any differences will greatly affect the child's psychological. Learning with peers will encourage students to take an active role in learning (Oh, 2019). The peer method enhances learning by themselves, students through experiences which are feedback from their friends (Gabriele et al., 2016). Peers help, guide, and support peers to build learning through interaction and collaboration (Andersen \& Watkins, 2018). Learning 
that involves peers will reduce anxiety and stress by being guided, assisted, and given peer feedback. Students will be able to increase self-confidence (Han et al., 2015; Stone et al., 2013). Learning using pop up book media will make students develop their social skills. We all know that inclusive education in regular classes, students experience weaknesses in social relationships (Bossaert et al., 2013; Schwab et al., 2018), students with special needs have lower learning outcomes than their peers without special needs (Zurbriggen et al., 2018), so that with the pop-up book media students will be more able to develop their social skills. It is following the advantages of Pop up Book media that are applied.

Pop up book media has several advantages so that it is suitable to be used to explain social studies material which tends to focus more on theory only. Pop up book media also provides a special experience for readers because it involves readers in the story, such as sliding, opening, and folding parts of the pop-up book (Sentarik \& Kusmariyatni, 2020). Some of the advantages of pop up book media compared to other media are (1) it can display images to be more attractive, (2) it can be used as teaching materials which can be used individually or in groups, (3) its use is very practical and can increase enthusiasm for learning students, (4) have a unique appearance, and this is an advantage of pop up book media compared to other media, (5) has an image dimension that arises when the page is opened (Masturah et al., 2018; Mustofa \& Syafi'ah, 2018). The pop-up book learning media applied in this research increases students' knowledge, especially in social science learning. Research on pop up book learning media. Mostly researched science material and improved science learning outcomes and only applied in regular schools, not inclusion. However, in this study, pop up book learning media was implemented to improve social studies knowledge in inclusive schools.
Based on the explanation above, it can be concluded that this study provides new findings that can help in the learning process so that learning can attract and make students in inclusive schools easier to understand social studies learning material so that learning objectives can be achieved. Pop up book media is suitable for use in the learning process of speech hearing deaf children because the learning style of deaf children is visual and a little bit kinesthetic. It causes the deaf child to learn visually towards the eyes or vision. The teacher uses visual media, body language, and facial expressions in the teaching and learning process. The pop-up book media increases the meaning of students' learning process with hearing impairments in inclusive schools. The implications of this research can later be used as a reference and can be used to teach any material in inclusive schools using pop up book media.

\section{CONCLUSION}

Based on the results of the data analysis that has been done, it can be concluded that the pop-up book learning media can improve the competence of social science knowledge for fourth-grade students in inclusive schools. It is suggested to other researchers that this study's results can motivate and can be used as a reference in developing similar pop-up book learning media or other media that are more attractive as learning media for students in social studies and other subjects.

\section{REFERENCES}

[1] Angela, T. (2014). Challenges to Meaningful Learning in Social Studies The Key Competences as an Opportunity to Students' Active Participation. Procedia - Social and Behavioral Sciences, 128, 192-197.

https://doi.org/10.1016/j.sbspro.2014.03.1

42

[2] Argikas, T. B., \& Khuzaini, N. (2016). Penerapan Model Pembelajaran 
Reciprocal Teaching Untuk Meningkatkan Pemahaman Konsep Matematika Siswa Kelas Vii Smp Negeri 2 Depok. Jurnal Mercumatika, 1(1), 67-79. https://jurnal.uns.ac.id/prosbi/article/viewF ile/18478/14652

[3] Arifin, M. Y., Kirana, T., \& Widodo, W. (2017). PEMBELAJARAN INKUIRI TERBIMBING UNTUK MENINGKATKAN KEMAMPUAN BERNALAR SISWA KELAS VI BERBANTUAN MEDIA BUKU POP UP. Jurnal Penelitian Pendidikan IPA, 2(1), 614.

https://doi.org/http://dx.doi.org/10.26740/j ppipa.v2n1.p6-10

[4] Armstrong, D., Armstrong, A. C., \& Spandagou, I. (2011). Inclusion: By choice or by chance? International Journal of Inclusive Education, 15(1), 29-39. https://doi.org/10.1080/13603116.2010.49 6192

[5] Aryawibawa, I. N., Putra Yadnya, I. B., Ngurah Parthama, I. G., \& Pye, C. L. (2018). Balinese spatial reference frames: Linguistic and non-linguistic evidence from the north of Bali. Lingua, 215, 4052.

https://doi.org/10.1016/j.lingua.2018.09.00 5

[6] Bossaert, G., Colpin, H., Pijl, S. J., \& Petry, K. (2013). Truly included? A literature study focusing on the social dimension of inclusion in education. International Journal of Inclusive Education, $\quad 17(1), \quad 60-79$. https://doi.org/10.1080/13603116.2011.58 0464

[7] Claudia, A. B., Valentini, C. B., \& Braun, K. C. R. (2015). Teacher education for inclusion: Can a virtual learning object help? Computers and Education, 85, 203210.

https://doi.org/10.1016/j.compedu.2015.02 .017

[8] D' alessio, S., Donnelly, V., \& Watkins, A. (2010). Inclusive education across Europe: the move in thinking from integration for inclusion. Revista de Psicologia y Educación, 1(5), 109-126. http://revistadepsicologiayeducacion.es/ind ex.php/volumenes/send/23-revistanumero-5-ao-2010/100revistaparte10watkins.html

[9] De Boer, A., Pijl, S. J., \& Minnaert, A. (2011). Regular primary schoolteachers' attitudes towards inclusive education: A review of the literature. International Journal of Inclusive Education, 15(3), 331-353. https://doi.org/10.1080/136031109030300 89

[10] Diacopoulos, M. M., \& Crompton, H. (2020). A systematic review of mobile learning in social studies. Computers and Education, 154(April), 103911. https://doi.org/10.1016/j.compedu.2020.10 3911

[11] Diahwati, R., Hariyono, H., \& Hanurawan, F. (2016). Keterampilan Sosial Siswa Berkebutuhan Khusus Di Sekolah Dasar Inklusi. Jurnal Pendidikan : Teori , Penelitian Dan Pengembangan, 1(8), 1612-1620. https://doi.org/http://dx.doi.org/10.17977/j p.v1i8.6682

[12] Diyantari, I. A. K. D., Wiyasa, N., \& Manuaba, S. (2020). Model Snowball Throwing Berbantuan Media Pop Up Book Berpengaruh Terhadap Kompetensi Pengetahuan Ipa. Jurnal Ilmiah Pendidikan Profesi Guru, 3(1), 9-21. https://doi.org/http://dx.doi.org/10.23887/ji ppg.v3i1.26973

[13] Hartini, S., Misbah, Dewantara, D., Oktovian, R. A., \& Aisyah, N. (2017). Developing learning media using online prezi into materials about optical equipments. Jurnal Pendidikan IPA Indonesia, 6(2), 313-317. https://doi.org/10.15294/jpii.v6i2.10102

[14] Herayanti, L., Habibi, H., \& Fuaddunazmi, M. (2017). Pengembangan Media Pembelajaran Berbasis Moodle 
pada Matakuliah Fisika Dasar. Jurnal Cakrawala Pendidikan, 36(2), 210-219. https://doi.org/10.21831/cp.v36i2.13077

[15] Hidayat, E. I. F., Vivi Yandhari, I. A., \& Alamsyah, T. P. (2020). Efektivitas Pendekatan Realistic Mathematics Education (RME) Untuk Meningkatkan Kemampuan Pemahaman Konsep Matematika Siswa Kelas V. Jurnal Ilmiah Sekolah Dasar, 4(1), 106. https://doi.org/10.23887/jisd.v4i1.21103

[16] Hutami, T. S., \& Hastuti, H. (2019). Keefektifan metode CIRC, role playing, dan VCT dalam meningkatkan hasil belajar IPS. Harmoni Sosial: Jurnal Pendidikan IPS, 6(1), 1-12.

[17] Ismail, A. (2018). Penerapan Model Pembelajaran Children Learning in Science (Clis) Berbantuan Multimedia Untuk Meningkatkan Penguasaan Konsep Fisika Siswa Sma. Jurnal Petik, 1(1), 19. https://doi.org/10.31980/jpetik.v1i1.55

[18] Karisma, I. K. E., Margunayasa, I. G., \& Prasasti, P. A. T. (2020). Pengembangan Media Pop-Up Book pada Topik Perkembangbiakan Tumbuhan dan Hewan Kelas VI Sekolah Dasar. Jurnal Ilmiah Sekolah Dasar, 4(2), 121. https://doi.org/10.23887/jisd.v4i2.24458

[19] Kostiainen, E., Ukskoski, T., Ruohotie-Lyhty, M., Kauppinen, M., Kainulainen, J., \& Mäkinen, T. (2018). Meaningful learning in teacher education. Teaching and Teacher Education, 71, 6677.

https://doi.org/10.1016/j.tate.2017.12.009

[20] Kusuma Wardani, R. F. A., Rifai, M., \& Mandalwati, T. K. (2017). Efektivitas Model Pembelajaran Clis Berbantuan Media Slide Powerpoint Terhadap Hasil Belajar IPA. Premiere Educandum: Jurnal Pendidikan Dasar Dan Pembelajaran, 7(02), 104. https://doi.org/10.25273/pe.v7i2.1596

[21] Liu, Y., Li, X., Chen, L., \& Qu, Z. (2015). Perceived positive teacher-student relationship as a protective factor for
Chinese left-behind children's emotional and behavioural adjustment. International Journal of Psychology, 50(5), 354-362. https://doi.org/10.1002/ijop.12112

[22] Marfuah, M. (2017). Improving Students' Communications Skills Through Cooperative Learning Models Type Jigsaw. Jurnal Pendidikan Ilmu Sosial, 26(2), 148. https://doi.org/10.17509/jpis.v26i2.8313

[23] Masturah, E. D., Mahadewi, L. P. P., \& Simamora, A. H. (2018). Pengembangan Media Pembelajaran PopUp Book pada Mata Pelajaran IPA Kelas III Sekolah Dasar. Jurnal EDUTECH Universitas Pendidikan Ganesha, 6(2), 212-221.

https://doi.org/http://dx.doi.org/10.23887/j eu.v6i2.20294

[24] Maulida, I., Dibia, I. K., \& Astawan, I. G. (2020). The Development of Social Attitude Assessment Instrument and Social Studies Learning Outcomes Grade IV on Theme of Indahnya Keragaman di Negeriku. Indonesian Journal of Educational Research and Review, 3(1), 12. https://doi.org/10.23887/ijerr.v3i2.25823

[25] Moriarty, E. (2020). "Sign to me, not the children": Ideologies of language contamination at a deaf tourist site in Bali. Language and Communication, 74, 195203.

https://doi.org/10.1016/j.langcom.2020.06. 002

[26] Mustika, D., \& Ain, S. Q. (2020). Peningkatan Kreativitas Mahasiswa Menggunakan Model Project Based Learning dalam Pembuatan Media IPA Berbentuk Pop Up Book. Jurnal Basicedu, 4(4), 1167-1175. https://doi.org/https://doi.org/10.31004/bas icedu.v4i4.518

[27] Mustofa, R., \& Syafi'ah, R. (2018). Pengembangan Media Pembelajaran Pop Up Book Materi Kenampakan Permukaan Bumi Mata Pelajaran IPA Kelas III SD. 
ELSE (Elementary School Education Journal), 2, 30-41. https://doi.org/http://dx.doi.org/10.30651/e lse.v2i2.1723

[28] Nikmah, S., Nuroso, H., \& Reffiane, F. (2019). Pengaruh Model Pembelajaran Terpadu Tipe Shared Berbantu Media Pop- Up Book Terhadap Hasil Belajar. Jurnal Pedagogi Dan Pembelajaran, 2(2), 264. https://doi.org/10.23887/jp2.v2i2.17920

[29] O'Connor, E. E., Dearing, E., \& Collins, B. A. (2011). Teacher-child relationship and behavior problem trajectories in elementary school. American Educational Research Journal, 48(1), 120-162. https://doi.org/10.3102/000283121036500 8

[30] Oswald, M. (2014). Positioning the individual teacher in school-based learning for inclusion. Teaching and Teacher Education, 37, 1-10. https://doi.org/10.1016/j.tate.2013.08.002

[31] Pratama, I. (2017). PENGARUH MODEL CLIS TERHADAP HASIL BELAJAR SISWA KELAS V THE EFFECT OF LEARNING MODEL CLIS TOWARD STUDENT LEARNING. MIMBAR PGSD Undiksha, 1(1), 324-342. https://doi.org/http://dx.doi.org/10.23887/jj pgsd.v1i1.818

[32] Putra, K. T. T., \& Parmiti, D. P. (2020). Topics of Animal and Human Respiratory System of the Fifth Grade Elementary Schools Developed Through Pop-Up Book Media. Journal of Education Technology, 4(2), 170. https://doi.org/10.23887/jet.v4i2.24970

[33] Rahmi, M. S. M., Budiman, M. A., \& Widyaningrum, A. (2019). Pengembangan Media Pembelajaran Interaktif Macromedia Flash 8 Pada Pembelajaran Tematik Tema Pengalamanku. International Journal Of Elementary Education, 3(2), 178-185. https://doi.org/10.23887/ijee.v3i2.18524
[34] Rencus, B. S. (2017). Peranan guru memilih model-model pembelajaran untuk meningkatkan kemampuan menulis puisi. Seminar Nasional Pendidikan Dasar Universitas Negeri Medan, 3-10. http://osf.io

[35] Rudi, R., Palimbong, A., \& Jamaludin, J. (2016). Meningkatkan hasil belajar siswa pada pembelajaran IPS dengan menggunakan media gambar di kelas IV SD Inpres 2 Ambesia Kecamatan Tomina. Jurnal Kreatif Tadulako Online, 4(6).

[36] Rusmawan, R. (2013). Faktor yang memengaruhi kesulitan belajar IPS siswa sekolah dasar. Jurnal Cakrawala Pendidikan, 2.

[37] Sabando, D., Puigdellívol, I., \& Torrado, M. (2019). Measuring the Inclusive profile of public elementary schools in Catalonia. International Journal of Educational Research, 96(June 2018), $1-20$.

https://doi.org/10.1016/j.ijer.2019.05.002

[38] Sari, A. C., Fadillah, A. M., Jonathan, J., \& Prabowo, M. R. D. (2019). Interactive gamification learning media application for blind children using android smartphone in Indonesia. Procedia Computer Science, 157, 589-595. https://doi.org/10.1016/j.procs.2019.09.01 8

[39] Schwab, S., Sharma, U., \& Loreman, T. (2018). Are we included? Secondary students' perception of inclusion climate in their schools. Teaching and Teacher Education, 75, 3139.

https://doi.org/10.1016/j.tate.2018.05.016

[40] Schwab, S., Zurbriggen, C. L. A., \& Venetz, M. (2020). Agreement among student, parent and teacher ratings of school inclusion: A multitrait-multimethod analysis. Journal of School Psychology, 82(July 2019), 1-16. https://doi.org/10.1016/j.jsp.2020.07.003

[41] Sentarik, K., \& Kusmariyatni, N. 
(2020). Media Pop-Up Book pada Topik Sistem Tata Surya Kelas VI Sekolah Dasar. Jurnal Ilmiah Sekolah Dasar, 4(2), 197.

https://doi.org/10.23887/jisd.v4i2.25135

[42] Septian, A., \& Tampubolon, J. (2015). Pengaruh Pembelajaran Menggunakan Media Tiga Dimensi (3D) Terhadap Hasil Belajar Menggambar Dengan Perangkat Lunak Kelas Xi Program Keahlian Teknik Gambar Bangunan Smk Negeri 2 Meulaboh. Educational Building, 1(1), 70-78. https://doi.org/10.24114/eb.v1i1.2827

[43] Sointu, E. T., Savolainen, H., Lappalainen, K., \& Lambert, M. C. (2017). Longitudinal associations of studentteacher relationships and behavioural and emotional strengths on academic achievement. Educational Psychology, 37(4), 457-467. https://doi.org/10.1080/01443410.2016.11 65796

[44] Spörer, N., Lenkeit, J., Bosse, S., Hartmann, A., Ehlert, A., \& Knigge, M. (2020). Students' perspective on inclusion: Relations of attitudes towards inclusive education and self-perceptions of peer relations. International Journal of
Educational Research, 103(November 2019), 101641. https://doi.org/10.1016/j.ijer.2020.101641

[45] Suarni, N. K., Suadnyana, I. N., \& Asri, I. G. A. A. S. (2013). Pengaruh Model Pembelajaran Learning Cycle 5E Terhadap Sikap Ilmiah Dan Hasil Belajar Ipa Siswa Kelas V Sd Negeri 5 Pedungan. Jurnal Jurusan Pendidikan Guru Sekolah Dasar, 1(1), 1-10. https://ejournal.undiksha.ac.id/index.php/J JPGSD/article/view/1460

[46] Triyanto, \& Permatasari, D. R. (2016). Pemenuhan Hak Anak Berkebutuhan Khusus Di Sekolah Inklusi. Sekolah Dasar: Kajian Teori Dan Praktik Pendidikan, 25(2), 176-186. https://doi.org/10.17977/um009v25i22016 p176

[47] Zurbriggen, C., Venetz, M., \& Schwab, S., Hessels, M. G. P. (2018). A psychometric analysis of the student version of the perceptions of inclusion questionnaire (PIQ). European Journal of Psychological Assessment. https://doi.org/https://doi.org/10.1027/ 1015-5759/a000443. 